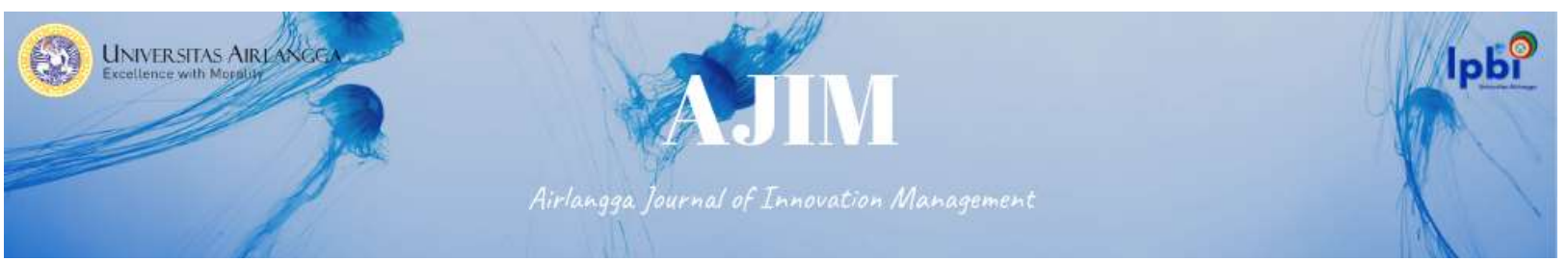

Vol.1 No.1 June 2020

ISSN: 2722-5062

DOI : 10.20473/ajim.v1i1.19402

\title{
THE EFFECT OF JOB CRAFTING ON INNOVATIVE BEHAVIOR THROUGH MEDIATION WORK ENGAGEMENT
}

\author{
Eferanda Risqyta Pradana ${ }^{1 *}$, Fendy Suhariadi ${ }^{2}$. \\ ${ }^{12}$ Faculty of Economics and Business, Universitas Airlangga \\ *E-mail: erizqy@gmail.com
}

\begin{abstract}
Innovation is one of the ways that must be done by companies through employees to stay competitive in the highly developed business competition in terms of technology and product innovation. The company restructurisation company results in the adjustment of employees in their work. This study aims to prove the role of job crafting as a solution for innovative behavior by involving work engagement variables as a mediator variable. This research uses a quantitative approach with data analysis using WarpPLS 6.0 from the data from questionnaires. The study population was employees of CV. Mapan Group. The results showed that job crafting had a significant positive effect on innovative behavior. Work engagement was significantly mediate the effect of job crafting on innovative behavior. These results indicate that in this study, partial mediation occurred on the effect of job crafting on innovative behavior through work engagement. Job crafting has a significant role in fostering employee engagement. Some ways that can be done for companies whose workforce is dominated by millennial are: 1) Doing passion mapping of employees and provide them wider opportunities, 2) Creating programs to align employees' personal missions with organizational missions, 3) Cultivating related competition work innovation as one of the strategies to stimulate employee job crafting.
\end{abstract}

Keywords: Job crafting, Work engagement, Innovative behavior, Restructurisation

\begin{abstract}
ABSTRAK
Inovasi adalah salah satu cara yang harus dilakukan oleh perusahaan melalui karyawan untuk tetap bertahan dan bersaing dalam persaingan bisnis yang sangat maju dalam hal teknologi dan inovasi produk. Adanya restrukturisasi di perusahaan menghasilkan penyesuaian karyawan dalam pekerjaan mereka. Penelitian ini bertujuan untuk membuktikan peran kerajinan kerja sebagai solusi untuk perilaku inovatif dengan melibatkan variabel keterlibatan kerja sebagai variabel mediator. Penelitian ini menggunakan pendekatan kuantitatif dengan analisis data menggunakan WarpPLS 6.0 dari data dari kuesioner. Populasi penelitian adalah karyawan CV. Grup Mapan, untuk sampel yang diperoleh adalah 31 responden. Hasil penelitian menunjukkan bahwa kerajinan kerja memiliki efek positif yang signifikan terhadap perilaku inovatif. Tes mediasi keterlibatan kerja pada pengaruh kerajinan kerja pada perilaku inovatif menunjukkan hasil yang signifikan. Hasil ini menunjukkan bahwa dalam penelitian ini mediasi parsial terjadi pada pengaruh kerajinan kerja pada perilaku inovatif melalui keterlibatan kerja. Job crafting memiliki peran penting dalam mendorong keterlibatan karyawan. Beberapa cara yang dapat dilakukan untuk perusahaan yang tenaga kerjanya didominasi oleh milenium adalah: 1) Melakukan pemetaan gairah dari karyawan dan kemudian memberi mereka peluang luas, 2) Membuat program untuk menyelaraskan misi pribadi karyawan dengan misi organisasi, 3) Memupuk kerja kompetisi terkait inovasi sebagai salah satu strategi untuk merangsang kerajinan kerja karyawan.
\end{abstract}

Kata kunci: Pekerjaan Kerajinan, Keterlibatan Kerja, Perilaku inovatif, Restrukturisasi 


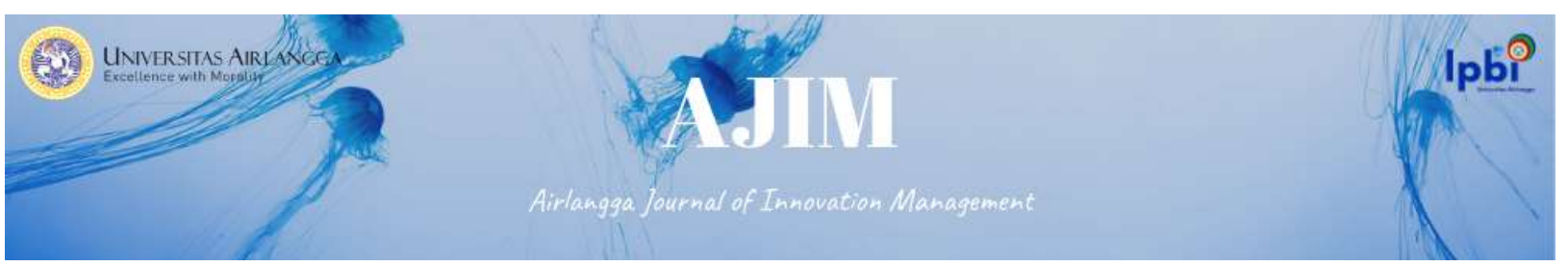

\section{INTRODUCTION}

The change of the economic era into a creative industry makes the dynamics of continuous change so that competition in the national and international market industry continues to experience growth. Economic changes require innovation in product development of creative industries. Companies with competitive advantages are companies that are able to create innovation and creativity through effective and structured processes. Innovation is used as a strategy to create and produce new products or make improvements by increasing innovative behavior in employees in the company (De Spieagelaere, 2014).

Human resource management is a very important concept because human factors as resources can produce competitive advantages for organizations and improve company performance to the maximum (Zekiri, 2015). The importance of innovative behavior is a concern to survive and develop in the industry (De Spieagelaere, 2014). Companies with competitive advantages are companies that can create innovation and creativity through effective and structured processes. Innovation is used as a strategy to create and produce new products or make improvements by increasing innovative behavior in employees in the company (De Spieagelaere, 2014).

The concept of applying innovative behavior is expected to accelerate the company's success in achieving the goals set (De Spieagelaere, 2014). Researchers assume that innovative behavior is the behavior of employees who directly and indirectly encourage the development and introduction of innovations in the workplace. This concept makes employees feel involved in generating new ideas and engaging in innovative activities. Some factors that influence innovative behavior directly include leadership, job characteristics, organizational commitment (Li \& Zheng, 2015), job demand (time pressure), job autonomy, and job insecurity (De Spieagelaere, 2014).

The company is important to develop and enhance innovation and creativity for its employees by creating higher innovative behavior to produce a competitive advantage for the company. Changes in how work is organized and displayed require employees to take certain steps that have an impact on the quality of work. Changes made by employees on their initiative to redesign the way they work are known as job crafting (Parker \& Collins, 2010). Job crafting is done to balance job demands with job resources (Tims, Bakker, \& Derks, 2012).

Job crafting presents an opportunity for the millennial generation workforce to integrate and organize work experience into an authentic sense of self. Job crafting is an individual effort in aligning work experience with internal encouragement that has an impact on the development of more intrinsic motivation where it can improve employee innovative behavior. Especially for millennial generation employees, it is expected to be encouraged to crafting work experience into activities that support company performance (Slemp \& Vella-Brodrick, 2014). Forms of employee adaptation with the company can be supported by proactive employee personalities, a spirit of dedication, self-initiative, and behavior that can provide a good chance in the future by increasing work engagement (Kooij, Kanfer, \& Tims, 2015).

Identification of various work demands and job resources in demographic groups, types of work, and certain industrial sectors can increase the effectiveness of work engagement interventions in the group (Bakker \& Albrecht, 2018). In addition to the challenges of doing company work engagement, it is also faced with the challenge of entering the millennial generation in the working world. The millennial have different thoughts and demands from previous generations. One tool to increase employee motivation is with work engagement where employees are given tasks and responsibilities that are usually performed by senior employees or supervisors and usually come with more freedom and control over planning, implementing, and evaluating work tasks (Herzberg, 2003). 


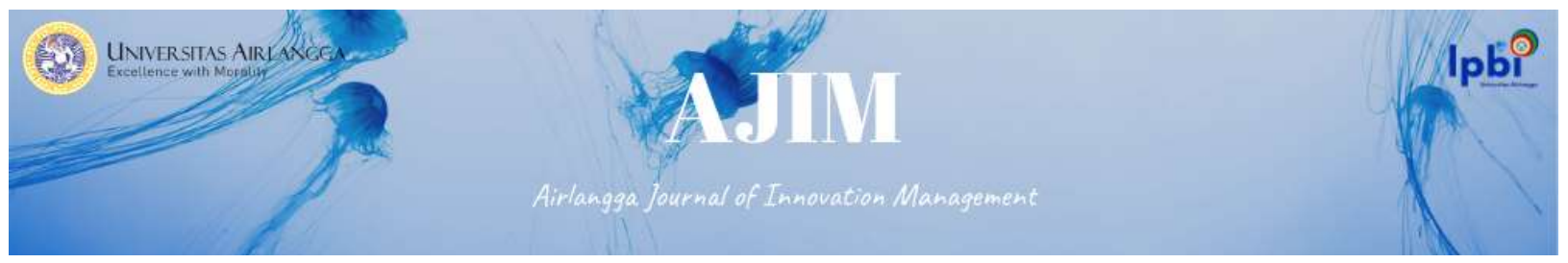

One example of the phenomenon of innovative behavior in companies can be seen from the results of the quality control group and the simplification of work processes. Companies are required to continue to be competitive in increasingly fierce and faster business competition, so the focus of innovation is directed at products, processes, or other aspects of company activities that lead to added value. This also happened in the CV. Mapan Group, where the company is aggressively carrying out activities that support innovation. This innovation activity is carried out by facilitating the appearance of innovative ideas and the implementation of the ideas of its employees so that the work process becomes efficient. Innovation problems occur when the company restructures. The positive impact of this restructuring is of course on work efficiency. But for the time being the policy of the directors has not yet been implemented about restructuring where the organizational structure is still too wide and working hours are currently working on Monday (8:00 to 17:00) and Saturday (07.30-13:00) where work hours like this deemed ineffective and employees are too long so that employees do not work optimally, later if implemented it will cause a policy of restructuring the company's structure and working hours. This policy must still be carried out by CV. Mapan Group as a form of organizational adjustment to the business environment that leads to cost efficiency and increased employee innovation.

Decisions and policies made by the company in implementing changes in operating working hours by conducting a review of organizational structure as a strategy in cost efficiency and maximizing employee performance. This simplified organizational structure has an impact on adjusting working hours and combining employees in one division so that later each division member can come up with ideas and innovations needed by the company. This simplification raises the existence of Job Crafting to be very important especially when there are changes in the characteristics, types, and environment in the world of work. When these changes are responded to by the opportunity to do job crafting, employees can have innovative behavior in these circumstances.

Referring to the results of theoretical studies that have been presented previously and related to changes in working hours and simplification of organizational structure in the CV. Mapan Group, researchers intend to examine the effect of job crafting on innovative behavior through work engagement. Previous research by De Spieagelaere (2014) involved the effect of job insecurity on innovative work behavior through work engagement. In this study, testing several hypotheses, one of which is the positive effect of job crafting on innovative behavior both directly and indirectly through work engagement.

\section{LITERATURE REVIEW}

In the research to be carried out by researchers, there are several theories used to support explanations and to support the analysis of the discussions to be carried out, namely the JD-R Model theory and the engagement model.

\section{Work Engagement \\ Definition of Work Engagement}

Work Engagement is one of the main problems faced by organizations or companies to retain their employees and try to ensure that employees make $100 \%$ effort in carrying out their duties (Robinson et al., 2004) defines Work engagement as a positive attitude held by employees towards organizational values and the company. Employees who are bound or involved consciously in the business context, and work with colleagues to improve performance on the job for the benefit of the organization.

(Husna, Mohd, \& Shafiqah, 2016) describe Work engagement as the level of commitment and involvement of employees that impacts on the organization or company where 


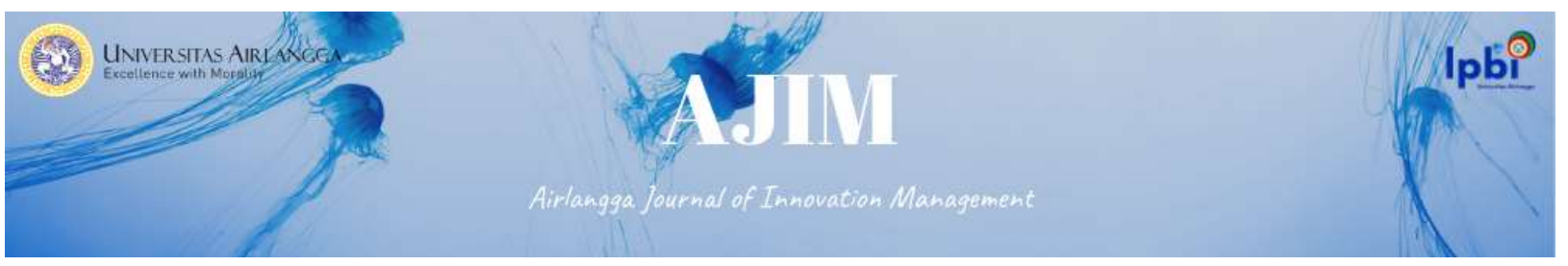

they work and its values. According to (Brunetto, Teo, Shacklock, \& Farr-Wharton, 2012) Work engagement is a measure of employees' emotional and intellectual commitment to the organization and its involvement. For this study using the theory of (Husna et al., 2016) because the company has values that must be carried out properly by employees so that the level of work engagement must be high where when commitment from employees is high and employee involvement in all problems in the company is high then will have an impact on improving employee and company performance.

\section{Work Engagement Dimensions}

(Schaufeli, Salanova, Bakker, \& Alez-rom, 2002) defines work engagement as a state with positive motivation, fulfillment, a view of working conditions that are characterized by vigor, dedication, and absorption. Based on the definition (Schaufeli, Salanova, Bakker, \& Alezrom, 2002) conceptualization of the dimensions of engagement, as follows:

1. Vigor, is an aspect that is characterized by high strength and mental resilience at work, the desire to work hard at work, and persistent when facing difficulties at work.

2. Dedication is a feeling that is full of meaning, enthusiasm, inspiration, pride, and challenging in its work to make its work a valuable, inspiring, and challenging experience. Besides dedication is also marked by a sense of enthusiasm and pride in his work.

3. Absorption, characterized by concentration and deep interest, sinking into his work, time that seems to pass quickly, and individuals who find it difficult to get away from work. Employees with high absorption rates are usually happy to spend time with their work and tend to have difficulty separating themselves from their work. As a result, the time while working becomes fleeting

\section{Factors that influence Work Engagement}

According to (Schaufeli, Salanova, Bakker, \& Alez-rom, 2002) work engagement is influenced by two things, namely the JD-R Model (Job demands-resources model) and psychological capital (psychological capital). JD-R Model includes several aspects such as the physical environment, social, organization, salary, career opportunities, support of supervisors and coworkers, freedom of self-improvement, and performance feedback. Whereas psychological capital includes self-confidence, optimism, hopes for the future, and resilience

When the company realizes the importance of utilizing resources with every potential it has, the company must facilitate and develop strategies to generate the three characteristics of work engagement above, because employees will be more engaged and contribute more when job demand and job resources run well and make it easier for employees to do job crafting with conditions in the company thereby increasing innovative behavior in the company.

\section{Job Crafting}

\section{Definition of Job Crafting}

Job Crafting is the behavior of employees changing support or challenges to be able to match their ability to do work (Kim, Im, \& Qu, 2018). Job Crafting as physical and cognitive changes made by individuals in the task or the relational boundaries of their work. Employees independently modify aspects of their work to increase the compatibility between job characteristics and their own needs, abilities, and preferences (Singh, 2018).

Job crafting is an employee's behavior changing support or challenges to be able to match his ability to do work. The change in question is the relationship with other employees at work, as well as perceptions about work to create a conducive work environment as a means of enriching work support (Kim, Im, \& Qu, 2018). 


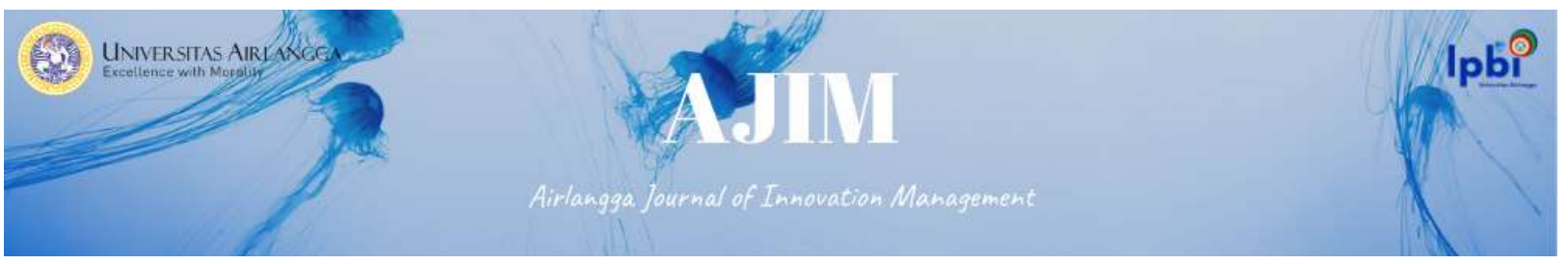

From the theory that has been explained by previous researchers, it can be concluded that job crafting is the behavior of employees utilizing the potential and ability possessed to change support or challenges in the work to be following their abilities to increase motivation at work.

\section{Job Crafting Dimensions}

Job crafting dimensions according to (Kim, Im, \& Qu, 2018) are categorized based on job crafting, the environment with which employees work together in work (relationship crafting), and work-related thinking (cognition crafting) as explained below:

1. Task crafting is changing the task at work that is by involving changes in the content of the job, both in the type or nature of the job.

2. Relationship crafting is a change in situations and conditions that involve changes in the quality and amount of interaction with others or change the style of interaction in work positions.

3. Cognition crafting is a change through views or thoughts by creating changes in perception of work

\section{Factors that influence Job Crafting}

Factors that influence job crafting according to Wrzesniewski \& Dutton (2001) include:

1. Personal control needs. This need is fundamental to being in control of several aspects of work. Employees are involved in job crafting to control their work. This is useful for maintaining interest in work and motivation in the workplace.

2. Positive self-image. Employees are motivated to create a positive self-image when working. Also, employees are motivated to maintain their self-image by forming jobs that fit their needs.

3. The need for social interaction. The basic needs that employees have are interacting with others. This serves to make a more positive work identity thereby increasing the meaning of work.

Based on the description above, the factors that influence job crafting are personal control needs, positive self-image, and social interaction needs. However, one of the factors that predict job crafting when associated with innovative behavior is a positive self-image that is motivated to create a positive self-image by forming work according to needs. This shows that in any situation, employees continue to make adjustments and innovate their work.

\section{Innovative Behavior}

\section{Definition of Innovative Behavior}

Innovative behavior is defined as the creation, introduction, and application of new ideas or ideas in work, groups, or organizations to improve the performance of the role of individuals, groups, or organizations (Janssen, 2000). According to Spiegelaere (2011), innovative behavior is a series of work activities that are gradually carried out by workers in developing and improving effective work behavior. Innovation can be interpreted as all individual actions directed at the interests of the organization in which the introduction and application of new ideas are beneficial (Jong \& Hartog, 2010).

From the theory explained by the researchers, it can be concluded that innovative behavior is the behavior of employees to develop and improve performance by creating, introducing, and applying new ideas in work that will benefit the employees and the company.

\section{Innovative Behavior Dimensions}




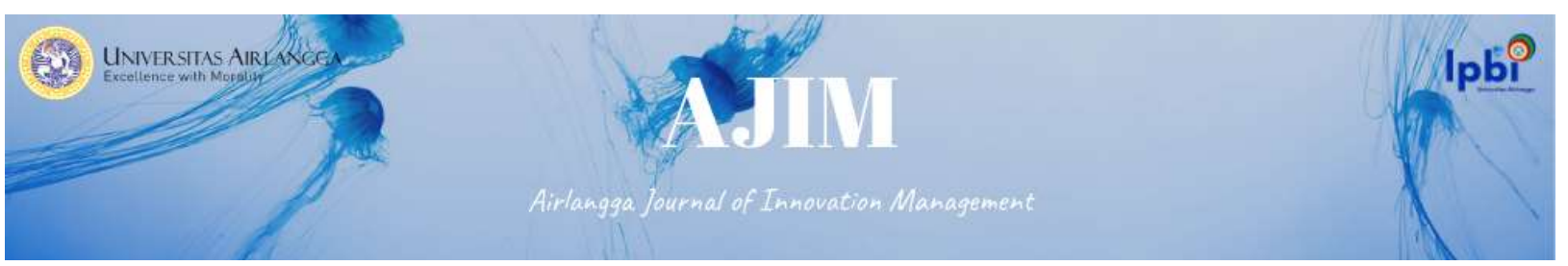

Spiegelaere (2011) measured innovative behavior by involving 2 dimensions, namely idea generation (exploring ideas and generating ideas) and idea implementation (promotion of ideas and application of ideas), each of which is explained as follows:

a. Exploring ideas (Idea exploration). Idea exploration is a dimension which is the initial stage of innovative behavior where employees can find an opportunity or a problem. This includes finding ways to develop products, services, and processes trying to think of other alternatives.

b. Generating ideas (Idea generation). Employees can recognize problems that occur in the organization and then create new ideas or solutions that are useful. The idea or solution can be original or modified from existing products and work processes.

c. Promoting ideas (Idea championing). Employees promote new ideas or solutions that have been created to colleagues so that these ideas can be accepted in the organization. At this stage, employees are expected to begin to be encouraged to seek support in realizing innovation ideas that have been generated. This includes finding coalitions so that new ideas can be implemented and trusting in the success of these ideas.

d. Implementation of ideas (Idea implementation). Employees produce a prototype or model of their ideas into tangible products and work processes so that they can be applied in the scope of work, groups, or the organization as a whole to improve organizational work efficiency

\section{Factors that influence Behavior}

Some factors can improve employees' innovative behavior. Nijenhuis (2015) suggests several external and internal factors, namely:

\section{External Factors}

a. Competitive pressures, the higher pressure to compete can encourage employees to work better and have a positive effect on the emergence of innovative behavior.

b. Social-Political pressures, organizations that have the support of the government must continue to provide satisfying work if they still want to get support. So leaders and employees must bring out innovative behavior to continue to provide good work.

\section{Internal factors}

a. Interaction with superiors (Leadership), employees who have a positive relationship with their superiors are more likely to show innovative work behavior and can provide confidence that their innovative behavior will produce work benefits.

b. Interaction with coworkers (Team Work), Employees who have a good relationship with coworkers makes it easier for them to implement new ideas and increase idea generation within their work team.

The factors that influence innovative behavior according to Yuan \& Woodman (2010), namely:

a. Climate and organizational culture

b. Relationship with superiors or attachment to superiors

c. Job characteristics are related to job understanding, job standardization, and job implementation.

d. Social/group context

e. Individual differences

\section{METHODS}

Data sources that will be used in this study are primary data. Primary data obtained by distributing questionnaires via Google form to employees in the company CV. Mapan Group. 


\section{Types of research}

In this research, the approach used is quantitative research. Judging from the relationships between elements, the type of research used is explanatory research, namely research that explains the causal relationship between research elements. In the implementation, information retrieval is done by taking from employees of CV. Mapan GroupThis is the part of your paper that explains how the research was done in no more than 2-3 pages. You should relate your research procedures in a clear, logical order so that other researchers can reproduce your results. Simply refer to the established methods you used, but describe any procedures that are original to your study in more detail.

\section{Operational Definition and Variable Measurement}

In this section, the author wants to explain the operational definition of each variable used. The following operational definitions of each variable along with the way to measure variables in this study:

Tabel 1

Operational Definition and Variable Measurement

\begin{tabular}{|c|c|c|c|}
\hline Variable & $\begin{array}{l}\text { Operational } \\
\text { definition }\end{array}$ & Variable Dimension & Measurement Scale \\
\hline Job Crafting (X) & $\begin{array}{l}\text { It is an employee's } \\
\text { behavior to change } \\
\text { support or } \\
\text { challenge to be } \\
\text { able to match his } \\
\text { ability to do work } \\
\text { (Kim, Im, \& Qu, } \\
2018 \text { ) }\end{array}$ & $\begin{array}{ll}\text { 1. } & \text { Task crafting } \\
\text { 2. } & \text { Relational } \\
& \text { Crafting } \\
\text { 3. } & \text { Cognitive } \\
& \text { Crafting } \\
& \text { (Kim, Im, \& Qu, } \\
& \text { 2018) }\end{array}$ & $\begin{array}{l}\text { Likert scale, with } \\
\text { alternative answers: } \\
\text { (1) Strongly Disagree } \\
\text { (2) Disagree } \\
\text { (3) Doubtful } \\
\text { (4) Agree } \\
\text { (5) Strongly agree }\end{array}$ \\
\hline $\begin{array}{l}\text { Work } \\
\text { Engagement (Z) }\end{array}$ & $\begin{array}{l}\text { Refers to that } \\
\text { individuals feel } \\
\text { passionate, have } \\
\text { the dedication and } \\
\text { give more } \\
\text { concentration to } \\
\text { work (Schaufeli et } \\
\text { al., 2008) }\end{array}$ & $\begin{array}{ll}\text { 1. } & \text { Vigor } \\
\text { 2. } & \text { Dedication } \\
\text { 3. } & \text { Absorption } \\
\text { (Schaufeli, 2002) }\end{array}$ & $\begin{array}{l}\text { Likert scale, with } \\
\text { alternative answers: } \\
\text { (1) Strongly Disagree } \\
\text { (2) Disagree } \\
\text { (3) Doubtful } \\
\text { (4) Agree } \\
\text { (5) Strongly agree }\end{array}$ \\
\hline $\begin{array}{l}\text { Innovative } \\
\text { Behavior (Y) }\end{array}$ & $\begin{array}{l}\text { refers to the } \\
\text { creation, } \\
\text { introduction, and } \\
\text { application of new } \\
\text { ideas by employees } \\
\text { and results in } \\
\text { improved } \\
\text { employee and } \\
\text { organizational } \\
\text { performance } \\
\text { (Janssen, 2000). }\end{array}$ & $\begin{array}{l}\text { 1. Idea Generation } \\
\text { 2. Idea Promotion } \\
\text { 3. Idea } \\
\quad \text { Implementation } \\
\text { (Janssen, 2000) }\end{array}$ & $\begin{array}{l}\text { Likert scale, with } \\
\text { alternative answers: } \\
\text { (1) Strongly Disagree } \\
\text { (2) Disagree } \\
\text { (3) Doubtful } \\
\text { (4) Agree } \\
\text { (1) (5) Strongly agree }\end{array}$ \\
\hline
\end{tabular}

\section{Data Types and Sources}

Sugiyono (2016) quantitative method can be interpreted as a research method based on the philosophy of positivism, used to examine specific populations or samples. Sampling techniques are usually done randomly, data analysis is quantitative or statistical to obtain more comprehensive, valid, reliable, and objective data. 


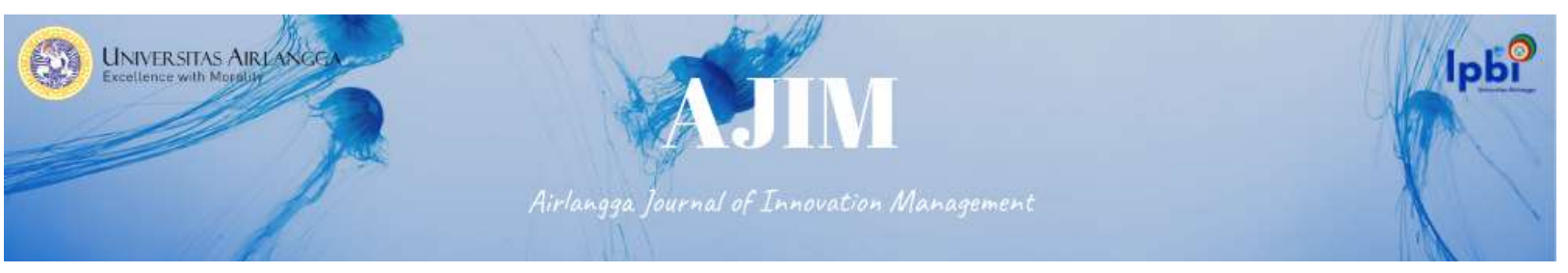

Based on the type of data, this study is research that uses primary data because the information obtained directly from the informant CV. Mapan Group

\section{Population and Research Samples}

The study population is the overall objective of the study (Syofian, 2012). The population in this study are employees who work in the company CV. Mapan Group.

The sample criteria used in this study are as follows:

1. Employees who work $>3$ months

2. Specialized in the HRD, B\&D, Auditor, Finance, Training \& Development, Marketing, and IT divisions.

In this study, the sampling technique used is non-probability sampling with the technique has taken is saturation sampling. According to Sugiyono (2014), The saturation sampling technique is the technique of determining the sample when all members of the population are used as samples. Where according to Sugiyono (2012) the size of a decent sample in the study was 30 to 500. The research sample above was taken because of a minimum 3-month work contract in a CV. Mapan Group amounts to $-/+30$ respondents which are spread across the divisions above. The division was chosen because for HRD and T\&D as well as B\&D and Auditors there will be a merging into one division while finance and marketing are chosen because it is directly related to the company's strategy related to profit sharing and market expansion of the company. Therefore, all of these divisions must adjust to the challenges of the job to raise innovative behavior that can improve company performance.

\section{Method of collecting data}

The main purpose of a study is to get accurate results, by knowing this data collection method, researchers will get data that has a standard that has been set (Sugiyono, 2016: 224). This technique is the most strategic way to conduct a study, especially explanatory research. In this study, the data collection method used is to use the questionnaire distribution method.

1. Questionnaire

For the questionnaire, this study uses a survey through a questionnaire distributed to several respondents who were sampled and using Google Form with the consideration that the millennial generation is more interested in filling out the questionnaire using a gadget.

\section{RESULT AND ANALYSIS}

In this study, the statistical analysis used is PLS (partial least square). PLS (partial least square) is a multivariate tool used to determine the relationship of several independent variables (X) namely job crafting to the dependent variable (Y) innovative behavior through work engagement $(Z)$.

According to Ghozali (2014) explains Partial Least Square is "a powerful factor indeterminacy of analysis methods because it does not assume the data must be with a certain scale measurement, the number of samples is small". The purpose of PLS is to assist researchers in obtaining the value of the variable for predictive purposes. This research uses a Partial Least Square (PLS) regression analysis tool. Researchers use the Warp PLS program that has been tested with a basic design and clear concepts. It is also easy to use (easy to use) and user friendly by using complete and easy features (Imam Ghozali, 2014). PLS as a multivariate statistical technique as a comparison between exogenous and endogenous variables with many indicators. 


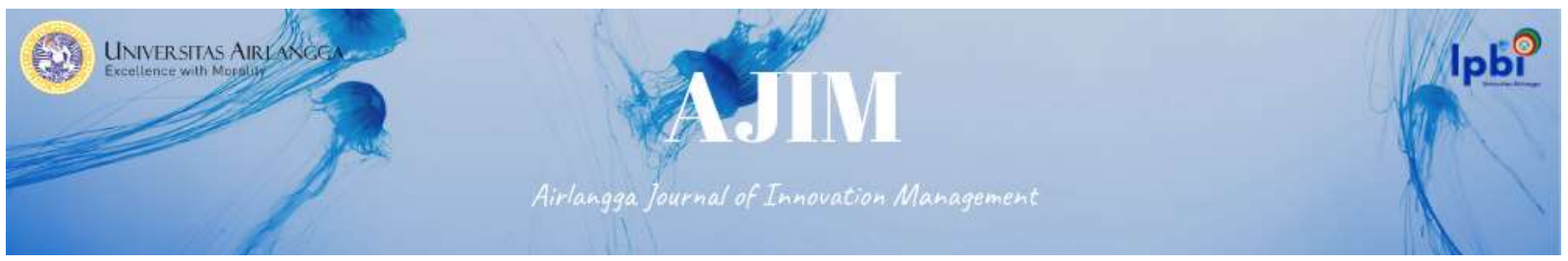

\section{RESULTS AND ANALYSIS \\ Hypothesis test}

Tabel 2

Correlations Among Latent Variables And Errors

Reflective Variable

\begin{tabular}{|c|c|c|c|c|c|c|c|c|c|c|}
\hline & & \multicolumn{3}{|c|}{$\mathrm{JC}$} & \multicolumn{3}{|c|}{ WE } & \multicolumn{3}{|c|}{ IB } \\
\hline & & TC & $\mathbf{C C}$ & RC & Vigor & Dedication & Absorption & IE & IG & IC \\
\hline \multirow{3}{*}{$\mathrm{JC}$} & TC & $(0.615)$ & 0.700 & 0.443 & -0.489 & -0.492 & -0.339 & 0.600 & 0.376 & 0.600 \\
\hline & $\mathbf{C C}$ & 0.700 & $(0.756)$ & 0.601 & -0.557 & -0.418 & -0.191 & 0.676 & 0.250 & 0.475 \\
\hline & RC & 0.443 & 0.601 & $(0.725)$ & -0.644 & -0.479 & -0.210 & 0.821 & 0.437 & 0.568 \\
\hline \multirow{3}{*}{ WE } & Vigor & 0.756 & 0.807 & 0.859 & $(0.738)$ & 0.565 & 0.487 & 0.827 & 0.429 & 0.692 \\
\hline & Dedication & -0.489 & -0.557 & -0.644 & 0.565 & $(0.705)$ & 0.630 & -0.815 & -0.489 & -0.662 \\
\hline & Absorption & -0.492 & -0.418 & -0.479 & 0.487 & 0.630 & $(0.541)$ & -0.596 & -0.523 & -0.444 \\
\hline \multirow{3}{*}{ IB } & IE & -0.339 & -0.191 & -0.210 & 0.768 & 0.876 & 0.848 & $(0.722)$ & 0.588 & 0.687 \\
\hline & IG & -0.520 & -0.468 & -0.486 & -0.815 & -0.596 & -0.373 & 0.588 & $(0.728)$ & 0.726 \\
\hline & IC & 0.600 & 0.676 & 0.821 & -0.662 & -0.444 & -0.539 & 0.687 & 0.726 & $(0.715)$ \\
\hline
\end{tabular}

\section{Source : Processed by authors with WarpPLS 6.0}

In the table above it can be seen that the value of the AVE root of each latent construct has a value above the AVE of the other construct. Then the results in this test have met Discriminant Validity.

In SEM-PLS using the Warp PLS 6.0 program. The reliability measurement of a construct can be done in two ways, namely by looking at Cronbach Alpha and Composite Reliability. However, the use of Cronbach Alpha to test construct reliability tends to have a lower value, so it is advisable to use Composite Reliability in testing reliability. Based on table 4.6 above, the results in this test meet the Composite Reliability with a value $>0.6$.

In testing the hypothesis, a discussion will be made about the results of the test consisting of the validity and reliability of the variables in the study and statistical analysis to solve the problems that exist in the study.

\section{Statistical Analysis}

Statistical analysis is used to solve the problems in this study using statistical test equipment. Following are the results of statistical tests using the PLS Warp program:

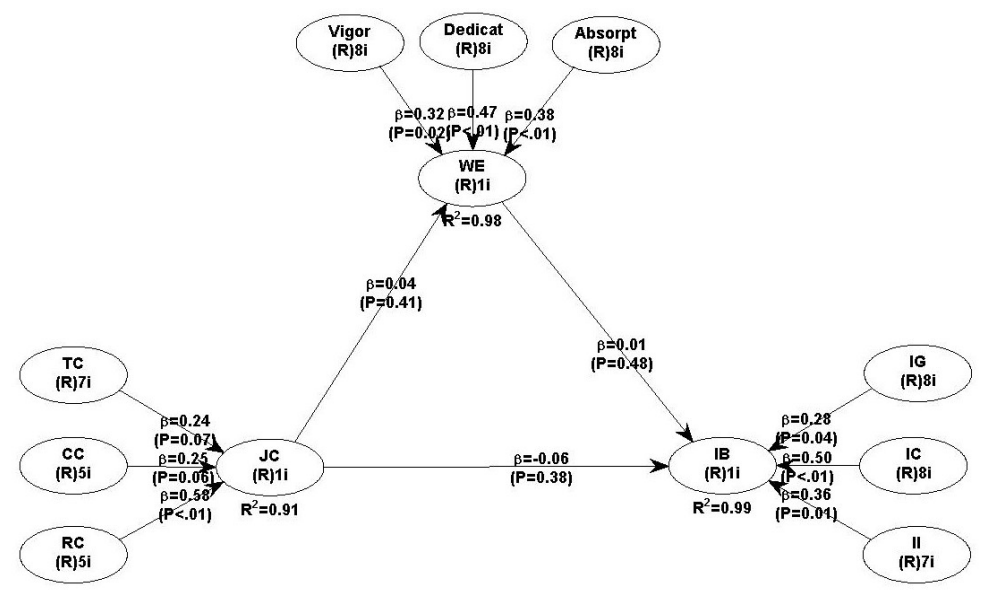

Figure 1 Research Model Source: Processed by authors 


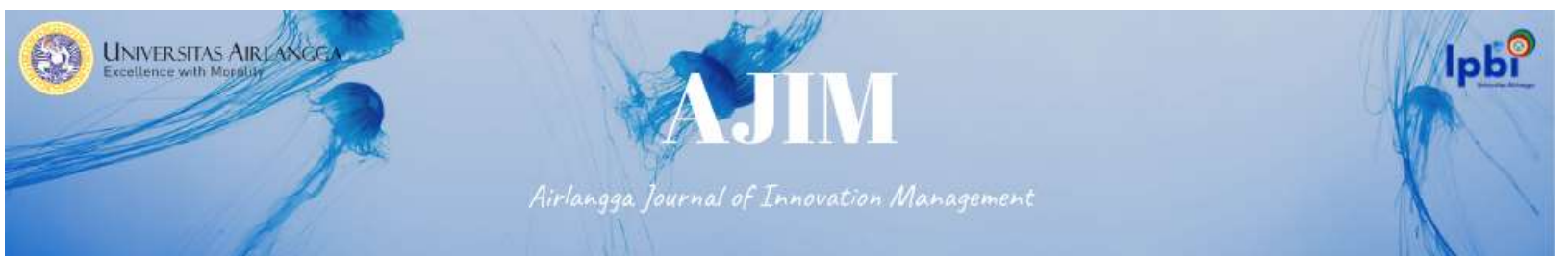

Based on the image estimation results above the model can be obtained PLS Warp output which will explain the results of the hypothesis proposed in this study, the following is the analysis:

1. Job Crafting (JC) has a significant negative effect on Innovative Behavior (IB) of -0.06 and a significance of $0.38(<0.5)$. With the first hypothesis that researchers formulated that Job Crafting had a significant positive effect on Innovative Behavior, then $\mathrm{H} 1$ was rejected.

2. Job Crafting (JC) has a significant positive direct effect on Work Engagement (WE) of 0.04 and a significance of $0.41(<0.5)$. Work Engagement (WE) has a significant positive direct effect on Innovative Behavior (IB) of 0.01 and a significance of $0.48(<0.5)$. While the RSquared of 0.98 shows how much the contribution of respondents has an impact on Innovative Behavior. Following the second hypothesis that researchers have formulated that Work Engagement mediates the effect of Job Crafting on Innovative Behavior, then $\mathrm{H} 2$ is accepted.

3. R2 value of 0.99 which means that the Job Crafting and Work Engagement variables influence the Innovative Behavior variable of $99 \%$ and the rest is influenced by other variables outside this study.

Job crafting has a positive effect on innovative behavior through work engagement. This positive influence supports the research conducted by (Mulyati, Himam, Riyono, \& Suhariadi, 2019). Job crafting perception requires that employees psychologically will create a new way for employees to the continuity of their work, to improve employee performance in bringing up new ideas in their work. Job crafting has a negative effect on innovative behavior in this study. This shows that the individual in the condition of job crafting psychologically will make the work demands are completed following the way and result in a decrease in innovative behavior when there is no work engagement on the employee.

Job crafting in addition to being a solution to innovation in work can also trigger an increase in new features in employment in terms of career advancement, income, or employment resources (Hellgren, 2010). Organizational restructuring can cause unknown and unpredictable changes in employee working conditions that include career opportunities, and other personal development. Although it influences employee working conditions, job crafting becomes very important especially when there are changes in the characteristics, type, and work environment (Mulyati et al., 2019), especially with employee behavior. When these changes are responded to by the opportunity to do job crafting, then employees can modify the environment or work to regain meaning in the work.

Job crafting is one of the job demand variables that is identical to the emergence of work engagement. The results of this hypothesis also reinforce previous research conducted by De Spiegelaere (2014). The results obtained indicate a positive influence between job crafting and innovative work behavior.

When reviewing the direct and indirect effects, it can be seen that the magnitude of the direct effect of job crafting on innovative behavior is 0.99 , while the indirect effect (through work engagement) is 0.98 . This shows that there are significant direct and indirect effects of job crafting on innovative behavior through work engagement. Also, the magnitude of the indirect positive effect of job crafting on innovative behavior through work engagement variables decreases when compared to the direct negative effect of job crafting on innovative behavior. These results indicate that there is a partial mediation in the effect of job crafting on innovative behavior through work engagement. 


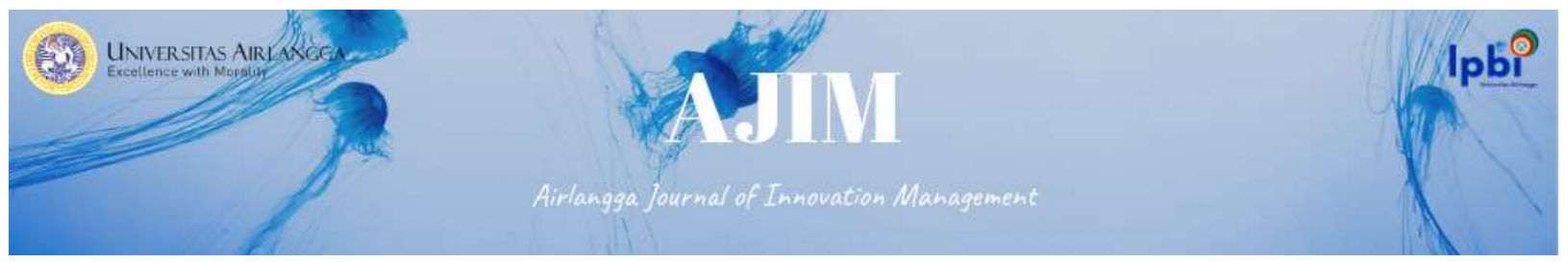

Job crafting has an indirect positive effect on innovative behavior through work engagement. Job crafting perception raises new things in a job. In this condition employees who only work based on job descriptions will not bring up innovation in their work. Based on the above understanding researchers assume that employees who only do work based on the description of their work can affect the level of work engagement. When employees perceive their work conditions comfortably, they will improve on Innovative behavior.

\section{CONCLUSION}

Based on the results of the research conducted, the author can conclude several things that can answer the problem formulation in this study. There is a significant negative direct effect of job crafting on innovative behavior. In testing the mediating role of work engagement shows a significant positive effect between job crafting on innovative behavior.

These results indicate that there is a partial mediation in job crafting of innovative behavior through work engagement mediation. Job crafting has a significant role in fostering employee engagement. Some ways that can be done for companies whose workforce is dominated by millennial are: 1) Doing passion mapping from millennial employees and then giving them wide opportunities to be able to develop themselves and get their work done in new ways that are more creative and innovative following their capacity to create a higher engagement at work, 2) Create programs to align the personal mission of millennial employees with the mission of the organization and work so that millennial employees can experience meaningful feelings at work, which in turn will be able to maintain or even increase work engagement 3) Cultivate competition related to work innovation as a strategy to stimulate the job crafting of millennial generation employees. Work innovation competition that is accompanied by an acknowledgment of the achievement of these performances can bring feelings of innovation related to their work and have implications for their engagement. The limitation of this study is that it only uses the Google form questionnaire, which will cause bias when making psychological measurements.

Future studies should use measurement data from a variety of sources, such as measuring the innovative work behavior of employees and conducting in-depth interviews with parties who play an important role in the company. This is done in order to provide comprehensive information about innovative behavior exhibited by employees and can compare assessments given by employees with their superiors.

\section{ACKNOWLEDGMENTS}

Authors indebted to their parents, friends, co-workers, and supervisor for their continued support and encouragement to motivate them to complete this study.

\section{REFERENCES}

Adkins, A. (2016). What millennials want from work. Gallup Business Journal, 1-4. Retrieved from http://www.gallup.com/businessjournal/191435/millennials-work-life.aspx

Akhavan Sarraf, A. R., Abzari, M., Nasr Isfahani, A., \& Fathi, S. (2017). Generational differences in job engagement: A case study of an industrial organization in Iran. Industrial and Commercial Training, 49(3), 106-115. DOI: 10.1108/ICT-10-2016-0068

Albrecht, S. L. (2013). Work engagement and the positive power of meaningful work. Advances in Positive Organizational Psychology, 1(2002), 237-260. DOI: 10.1108/S2046410X(2013)0000001013

Ardy, L. P. (2018). Pengaruh job insecurity terhadap perilaku kerja inovatif melalui mediasi work engagement. Jurnal Psikologi (2018) 


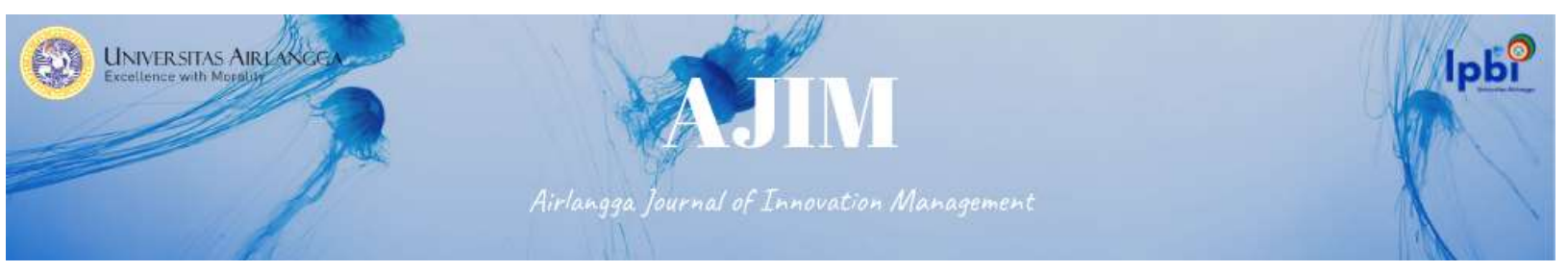

Bakker, A. B., Demerouti, E.,\& Euwema, M. C. (2005). Job resources buffer the impact of job demand on burnout. Journal of Occupational Health Psychology, 10, 170-180

Bakker, A. B., \& Schaufeli, W. B. (2008). Positive organizational behavior: Engaged employees in flourishing organizations. Journal of Organizational Behavior, 29, 147-154.

Bal, P. M., \& Kooij, D. (2011). The relations between work centrality, psychological contracts, and job attitudes: The influence of age.European Journal of Work and Organizational Psychology, 20, 497-523.

Baron, Angela \& Armstrong, Michael. (2013). Human CapitalManajemen: Konsep dan Implementasi.(Terjemahan Lilian Juwono).Penerbit PPM.Jakarta.

Chawla, D., Dokadia, A., \& Rai, S. (2017). Multigenerational differences in career preferences, reward preferences, and work engagement among Indian employees. Global Business Review, 18(1), 181197. DOI: $10.1177 / 0972150916666964$

Chang, Huo-Tsan, Hung-Ming Hsu, Jia-Wen Liou, Chi-Tung Tsai (2013). "Psychological Contracts and Innovative Behavior: A Moderate Path Analysis of Work engagement and Job Resources" Journal of Applied Social Psychology Vol. 43, pp. 2120 - 2135.

De Jong, J., \& Den Hartog, D., (2010). Measuring innovative work behavior. Journal of Creativity And Innovation Management, 19, (1), 23 - 36.

Demerouti, E., Bakker,A. B.,Nachreiner, F., \& Schaufeli, W. B. (2001). The job demands-resources model of burnout. Journal of Applied Psychology, 86, 499- 512

Derek T, Laura H. Human Resource Management-The inside out, 4th ed. England: Prentice Hall Publisher, 2000.

Deepa, M. Stella. 2012. Employee Turnover in the IT Industry with Special Reference to Chennai City an Exploratory Study. Vol 2 Iss:7 pp. 160- 177

De Spieagelaere. (2014). On the relation of job insecurity, job autonomy, innovative work behavior, and the mediating effect of work engagement. Creativity and Innovation Management, 23(3), 318-330. http://psycnet.apa.org/record/2014-30897-001 DOI: https://doi.org/10. 1111/caim.12079 online diakses October 2018.

De Spieagelaere. (2015).job design in innovative work behavior through work engagement. Psychology behavior, 45-61. DOI: https://doi.org/10.12211/caim.11259 online diakses October 2018.

De Spieagelaere. (2016) not all autonomy is the same as innovative work behavior. DOI: https://doi.org/10.1111/caim.11458 online diakses October 2018.

Frankl, V.E. (1984). Man's search for meaning: An introduction to logotherapy. Boston, MA: Beacon Press.

Ghozali, I. (2006). Structural Equation Modeling, Metode Alternatif Dengan Partial Least Square. Semarang: Badan Penerbit UNDIP.

Ghozali, I dan Latan, H. (2015). Partial Least Squares: Konsep, Teknik dan Aplikasi Menggunakan Program SmartPLS 3.0. Semarang: Badan Penerbit UNDIP.

Ghozali, I. (2011). Model persamaan struktural: Konsep dan aplikasi dengan program AMOS 24 (Edisi 7). Semarang: Badan Penerbit Universitas Diponegoro

Setyawati, S. M. (2019). Praktik sdm, job crafting dan work engagement terhadap kinerja karyawan. Jurnal Ilmu Manajemen (JIM), 7(3), 619-628.

Hallberg, Ulrika E. \& Wilmar B Schaufeli (2006). "Same Same But Different? Can Work engagement Be Discriminated from Job Involvement and Organizational Commitment"? European Psychologist, Vol. 11, No.2, pp $119-127$

Howe, N., \& Strauss, W. (2007). The Next 20 Years: How Customer and Workforce Attitudes Will Evolve. Harvard Bussiness Review, 85, 41-52.

Janssen, O. (2000). Job demands, perceptions of effort-reward fairness, and innovative work behavior. Journal of Occupational and Organizational Psychology,73, 287-302

Janssen, O., \& Van Yperen, N. W. (2004). Employees' goal orientations, the quality of leader-member exchange, and the outcomes of job performance and job satisfaction. Academy of Management Journal, 47, 368-384

Jong, De \& Den Hartog, 2008. "Leadership as a determinant of innovative behavior". A Conceptual framework. 2008. "Innovative and Work 88|A irlangga Journal of Innovation Management, Vol.1 ( 1) June 2020 


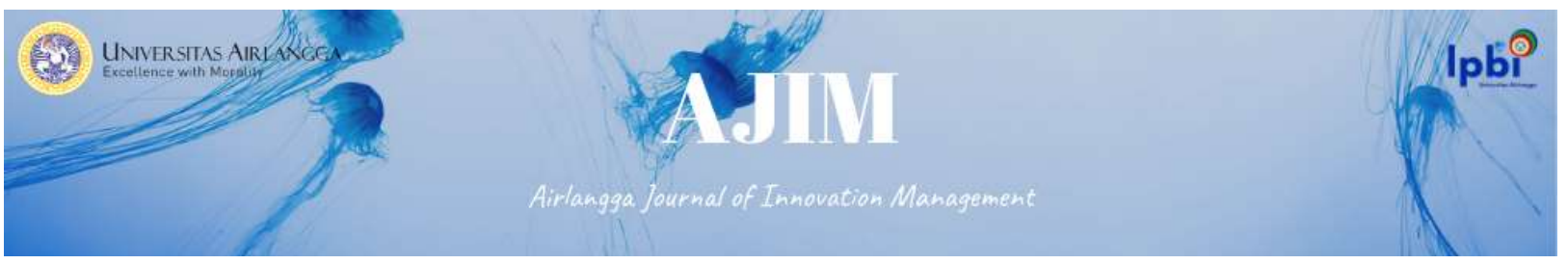

Behavior : Measurement and Validation. Amsterdam: EIM Bussiness.

Jusuf Zekiri, N. I. (2015). The Importance of Motivation Factors on Employee Performance in Kosovo Municipalities. Journal of Political Sciences \& Public Affairs, 03(02), 2-7. https://doi.org/10.4172/2332-0761.1000152

Kahn, W. A. (1990). Psychological conditions of personal engagement and disengagement at work. Academy of Management Journal, 33, 692-724.

Kahn, W. A. (1992). To be fully there: Psychological presence at work. Human Relations, 45, 321-349

Kooij, D., Kanfer, R., \& Tims, M. (2015). Successful aging at work: the role of job crafting. Springer International Publishing Switzerland.

Kilber, J., Barclay, A., \& Ohmer, D. (2014). Seven Tips for Managing Generation Y. Journal of Management Policy and Practice, 15, 4-9.

Kim, H., Im, J., \& Qu, H. (2018). Exploring antecedents and consequences of job crafting. International Journal of Hospitality Management, 75, 18-26. https://doi.org/10.1016/j.ijhm.2018.02.014

Kim, M., \& Beehr, T. A. (2018a). Can Empowering Leaders Affect Subordinates' Well-Being and Careers Because They Encourage Subordinates' Job Crafting Behaviors? Journal of Leadership and Organizational Studies, 25(2), 184-196. https://doi.org/10.1177/1548051817727702

Kim, M., \& Beehr, T. A. (2018b). Can Empowering Leaders Affect Subordinates' Well-Being and Careers Because They Encourage Subordinates' Job Crafting Behaviors? Journal of Leadership \& Organizational Studies, 25(2), 184-196. https://doi.org/10.1177/1548051817727702

Kupperschmidt, B. (2000). Multigenerational Employees: StrategicFor Effective Management. Health Care Manage, 19, 65-76

Li, X., \& Zheng, Y. (2015).The Influential Factors of Employees' Innovative Behavior and Management Advice. Journal of Service Science and Management, 7(06), 446.

Lyons, S. (2004). An Exploration of generational Values In Life and At Work. ProQuest Dissertations and Theses, 411-441.

Lee, D. (2017). Millennials and meaningfulness at work (Disertasi doctoral). Diunduh dari ProQuest Dissertations Publishing. (UMI No. 10605489)

Lewis, P. N., \& Yeoman, R. (2016). Busting the millennial myth-the power of purpose: An inquiry into the millennial generation's attitude towards working in employee-owned businesses and how they can prosper in millennials' hands. Diunduh dari http://www.fieldfisher.com/media/4948679/eomillennia web.pdf

Lips-Wiersma, M., \& Wright, S. (2012). Measuring the meaning of meaningful work: Development and validation of the Comprehensive Meaningful Work Scale (CMWS). Group and Organization Management, 37(5), 655-685. DOI: 10.1177/1059601112461578

Mello, Jeffrey A. (2011). Strategic Management of Human Resources.3rd edition.South-Western, Cengage Learning.Canada.

Mulyati, R., Himam, F., Riyono, B., \& Suhariadi, F. (2019). Model regresi keterlibatan kerja tenaga kerja millennial. Manuskrip tidak dipublikasikan, Fakultas Psikologi dan Ilmu Sosial Budaya, Universitas Islam Indonesia, Yogyakarta

Nakamura, S., \& Otsuka, Y. (2012). Job resources enhance work engagement through positive affect and meaningful work among Japanese employees. In F. Sarraci (Ed.), Psychology of emotions, motivations, and actions. The happiness compass: Theories, actions, and perspectives for wellbeing (pp. 141-151). Hauppauge, NY, US: Nova Science Publishers

Ng, E. S. W., Schweitzer, L., \& Lyons, S. T. (2010). New generation, great expectations: A field study of the millennial generation. Journal of Business and Psychology, 25(2), 281-292. https://doi.org/10.1007/s10869-010-9159-4

Nnambooze, B. E., \& Parumasur, S. B. (2016). Understanding The Multigenerational Workforce: Are The Generations Significantly Different or Similar? Corporate Ownership and Control, 13, 244257

Parker, S. K., \& Collins, C. G. (2010). Taking stock: Integrating and differentiating multiple proactive behaviors. Journal of Management, 36(3), 633-662. DOI: 10.1177/0149206308321554. 


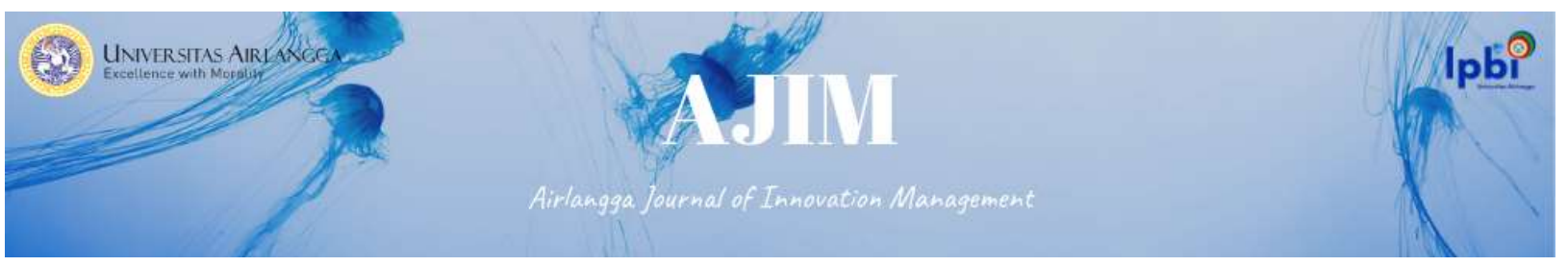

Perry-Smith, J. E., \& Shalley, C. E. (2003). The social side of creativity: A static and dynamic social network perspective. Academy of Management Review, 28, 89-106

Prijono Sugiarto (21 Februari 2011). Net Quality income Astra capai Rp. 4 triliun. dari http://www.infobanknews.com

Raja, U., Johns, G., \& Ntalianis, F. (2004). The impact of personality on psychological contracts. Academy of Management Journal, 47, 350-367.

Rich, B. L., Lepine, J. A., \& Crawford, E. R. (2010). Job engagement: Antecedents and effects on job performance.Academy of Management Journal, 53, 617-635

Robinson, D., Perryman, S., \& Hayday, S. (2004). The drivers of employee engagement. Brighton, UK: Institute for Employment Studies

Robbins SP, Judge TA. Organizational behavior ( $14^{\text {th }}$ ed.). Upper Saddle River, NJ: Prentice-Hall, 2011

Roberts, E. B. (2007). Managing invention and innovation. Research-Technology Management, 50, 3554.

Rousseau, D. M. (1989). Psychological and implied contracts in organizations. Employee Responsibilities and Rights Journal, 2, 121-139.

Rousseau, D. M. (1990). New hire perceptions of their own and their employer's obligations: A study of psychological contracts. Journal of Organizational Behavior, 11, 389-400.

Rousseau, D. M. (1995). Psychological contracts in organizations: Understanding wrote and unwritten agreements. Thousand Oaks, CA: Sage.

Rousseau, D. M. (1996). Changing the deal while keeping the people. Academy of Management Executive, 10, 50-59.

Rousseau, D. M. (1998). Assessing psychological contracts: Issues, alternatives, and measures. Journal of Organizational Behavior, 19, 679-695.

Ryan, R. M., \& Deci, E. L. (2000). Self-determination theory and the facilitation of intrinsic motivation, social development, and well-being. The American Psychologist, 55, 68-78.

Schaufeli, W. B., \& Bakker, A. B. (2004). Job demands, job resources, and their relationship with burnout and engagement: A multi-sample study. Journal of Organizational Behavior, 25, 293-315.

Schaufeli, W. B., Salanova, M., González-Romá, V., \& Bakker, A. B. (2002).The measurement of engagement and burnout: A two sample confirmatory analytic approach. Journal of Happiness Studies, 3, 71-92.

Schmidt, F. L.,\& Hunter, J. E. (1996).Measurement error in psychological research: Lessons from 26 research scenarios. psychological methods, 1, 199-223.

Scott, S. G.,\& Bruce, R.A. (1994). Determinants of innovative behavior: A path model of individual innovation in the workplace. Academy of Management Journal, 37, 580-607.

Shalley, C. E., Zhou, J., \& Oldham, G. R. (2004). The effects of personal and contextual characteristics on creativity: Where should we go from here? Journal of Management, 30, 933-958.

Slemp, G. R., \& Vella-Brodrick, D. A. (2014). Optimizing employee mental health: The relationship between intrinsic need satisfaction, job crafting, and employee well-being. Journal of Happiness Studies, 15(4), 957-977. DOI: 10.1007/s10902-013-9458-3

Sugiyono. 2016. Metode Penelitian Pendidikan Pendekatan Kuantitatif, Kualitatif, dan R \& D. Bandung: Alfabeta

Solnet, D., \& Hood, A. (2008). Generation Y as Hospitality Employees: Framing a Research Agenda. Journal of Hospitality and Tourism Management, 15, 59-68.

Overell, S. (2008). Inwardness: The rise of meaningful work. London: The Work Foundation. Retrieved from http://www.theworkfoundation.com/assets/docs/publications/32_inwardness_final.pdf

Saks, A.M. (2006). Antecedents and consequences of employee engagement. Journal of Managerial Psychology, 21 (6), 600-619

Sugiyono. (2010). Metode Penelitian Pendidikan, Pendekatan Kuantitatif, Kualitatif, dan R\&D. Bandung: Alfabeta.

Sugiyono. (2016). Metode Penelitian Kuantitatif, Kualitatif dan R\&D. Bandung: PT Alfabet.

Setyawati, S. M. (2019). Praktik sdm, job crafting dan work engagement terhadap kinerja karyawan. Jurnal Ilmu Manajemen (JIM), 7(3), 619-628. 


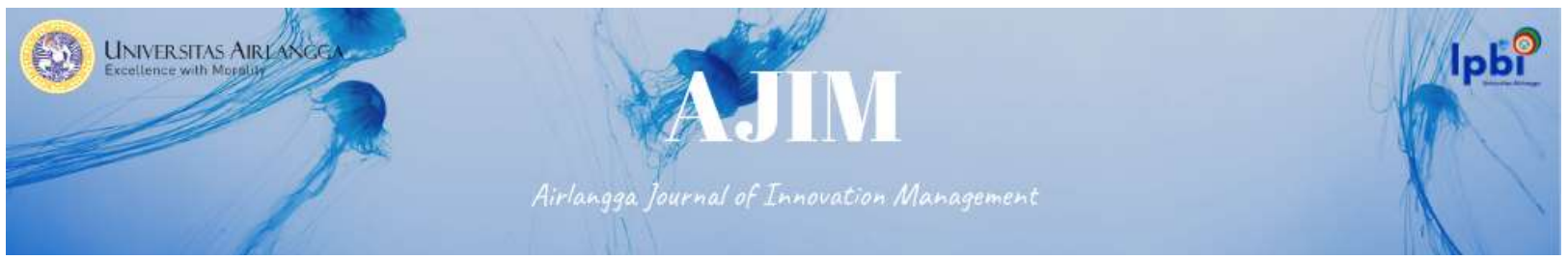

Spielgelaere, Stan De, Guy Van Gyes \& Geert Van Hootegem (2012). "Job Design and Innovative Work Behavior: One Size Does Not Fit All Types of Employees” Journal of Entrepreneurship, Management, and Innovation. Vol. 8, No. 4, pp 5 - 20

Tims, M., Bakker, A., \& Derks, D. (2012). Development and validation of the job crafting scale. Journal of Vocational Behavior, 173-186.

Tims, M., Bakker, A. B., \& Derks, D. (2014). Job crafting and job performance: A longitudinal study. European Journal of Work and Organizational Psychology, 24(6), 914-928. http://doi.org/10.1080/1359432X.2014.969245

Tims, M., Derks, D., \& Bakker, A. (2016). Job crafting and its relationship with person job-fit and meaningfulness: a three-wave study. Journal of Vocational Behavior, 42-53.

Van Emmerik, I. J. H., Euwema, M. C., \& Bakker, A. B. (2007). Threats of workplace violence and the buffering effect of social support. Group \& Organization Management, 32, 152-175.

Setyawati, S. M. (2019). Praktik sdm, job crafting dan work engagement terhadap kinerja karyawan. Jurnal Ilmu Manajemen (JIM), 7(3), 619-628.

Xanthopoulou, D., Bakker, A. B., Demerouti, E., \& Schaufeli, W. B. (2007). The role of personal resources in the job demands-resources model. International Journal of Stress Management, 14, $121-141$.

Xanthopoulou, D., Heuven, E., Demerouti, E., Bakker, A. B., \& Schaufeli, W. B. (2008). Working in the sky: Diary study on work engagement among flight attendants. Journal of Occupational Health Psychology, 13, 345-356.

Zhang, X., \& Bartol, K. M. (2010). Linking empowering leadership and employee creativity: The influence of psychological empowerment, intrinsic motivation, and creative process engagement. Academy of Management Journal, 53, 107-128.

Zhang, Y.; Feng, X. (2011). The Relationship Between Job Satisfaction, Burnout, and Turnover Intention Among Physicians from Urban State-Owned Medical Institutions in Hubei, China: A CrossSectional Study. 24(11). 